\title{
Analysis of Bank Performance and the Risks Assumed
}

\author{
Viorica IOAN ${ }^{\star}$, Ioana LAZARESCU ${ }^{\star \star}$, Costinela FORTEA ${ }^{\star \star \star}$
}

\begin{tabular}{l}
\hline \multicolumn{1}{c}{ A R T I C L E I N F O } \\
\hline Article history: \\
Accepted March 2020 \\
Available online May 2020 \\
\hline JEL Classification \\
G21, G32 \\
Keywords: \\
Banking performance, Profit, \\
return on economic, Financial \\
return, Bank management
\end{tabular}

\begin{abstract}
A B S T R A C T
One of the main objectives is to optimize profits of the banks, bank performance indicates its stability and depositor confidence so should be encouraged to obtain the greatest possible performance for a stable financial system. Bank management is profit-driven, that is a top banking performance. In banking practice, various instruments for measuring and reporting bank performance are known, but one of the most efficient is the system of indicators used for this purpose. Therefore, in this paper we analyzed key indicators for assessing the performance of banking insitutions namely return on assets (ROA), return on equity (ROE), leverage, net profit rate and asset utilization. These indicators of appreciation of bank performance are highly expressive, reflecting a multitude of aspects such as the degree of profit generation, operational and managerial efficiency.
\end{abstract}

(C) 2020 EAI. All rights reserved.

\section{Introduction}

The main objective of a bank managing is to obtain profits. Profitability in the form of retained earnings, is one of the key sources of capital generation. Profitability is a revealing indicator of the bank's competitive position in banking markets and the quality of its management. problems

This allows a bank to maintain a certain risk profile and offers protection against short-term

The profit and loss account is a key source of information on the profitability of the bank, reveals the sources of profit of a bank and their quantity and quality, as well as the quality of the bank's loan portfolio and the concentration of its expenses.

Taxation is another major factor that influences the profitability of a bank, as well as its policy and business options, as it affects the competitiveness of various instruments and segments of financial markets.

Banking risk can be defined as a phenomenon that occurs during the course of the banking activities and causes negative effects on these activities by deteriorating the quality of the assets, the profits or even the recording of losses, all affecting the functionality of the bank. (Cociș, Andries 2009).

From the National Bank of Romania perspective, the risks that can significantly affect the assets, situation or reputation of a banking institution are: credit risk, country risk, market risk, currency risk, interest rate risk, liquidity risk, operational risk, legal and reputational.

According to Dardac N. (2001), a bank may face certain types of risks, being divided into two categories: general risks and specific risks. Within the general risks category can be included:

* commercial risks (customer / product risk, market risk, commercial image risk);

* risks related to property and persons (accidents risk, crime risk);

$\$$ operational and technical risks (risk of treatment operations, the risk related to telecommunications system);

+ internal management risk (regulatory risk, deontological risk, strategic risk, functional failure risk, personnel management risk, technological dependency risk, communications risk);

Banks specific risks include:

* financial risks (interest rate risk, liquidity risk, risk on variable income securities);

* signature or counterparty risks (customer risk, interbank risk, country risk);

The risk in banking is defined in the work of Professor Eddie Calle, who believes that "the risk is exposure to uncertainty banking".

\section{Banking performance}

Performance can be defined as the measure of stability of the bank's activity, with low levels of risk of any kind and a normal growth trend of profits from a time-assay. 
Performance management intersects with that of the field of banking management, the quality is reflected in the bank's performance, directly linked to the management of bank assets and liabilities, and reflected in the balance sheet and profit and loss account. Therefore, bank management aims to make a profit, that is, superior banking performance.

The overall performance of a bank characterizes its overall results, is given in the international standards of the level of profitability of the capital of the banking company, correlated with its variation according to the resources assumed by the respective bank. Figure 1.

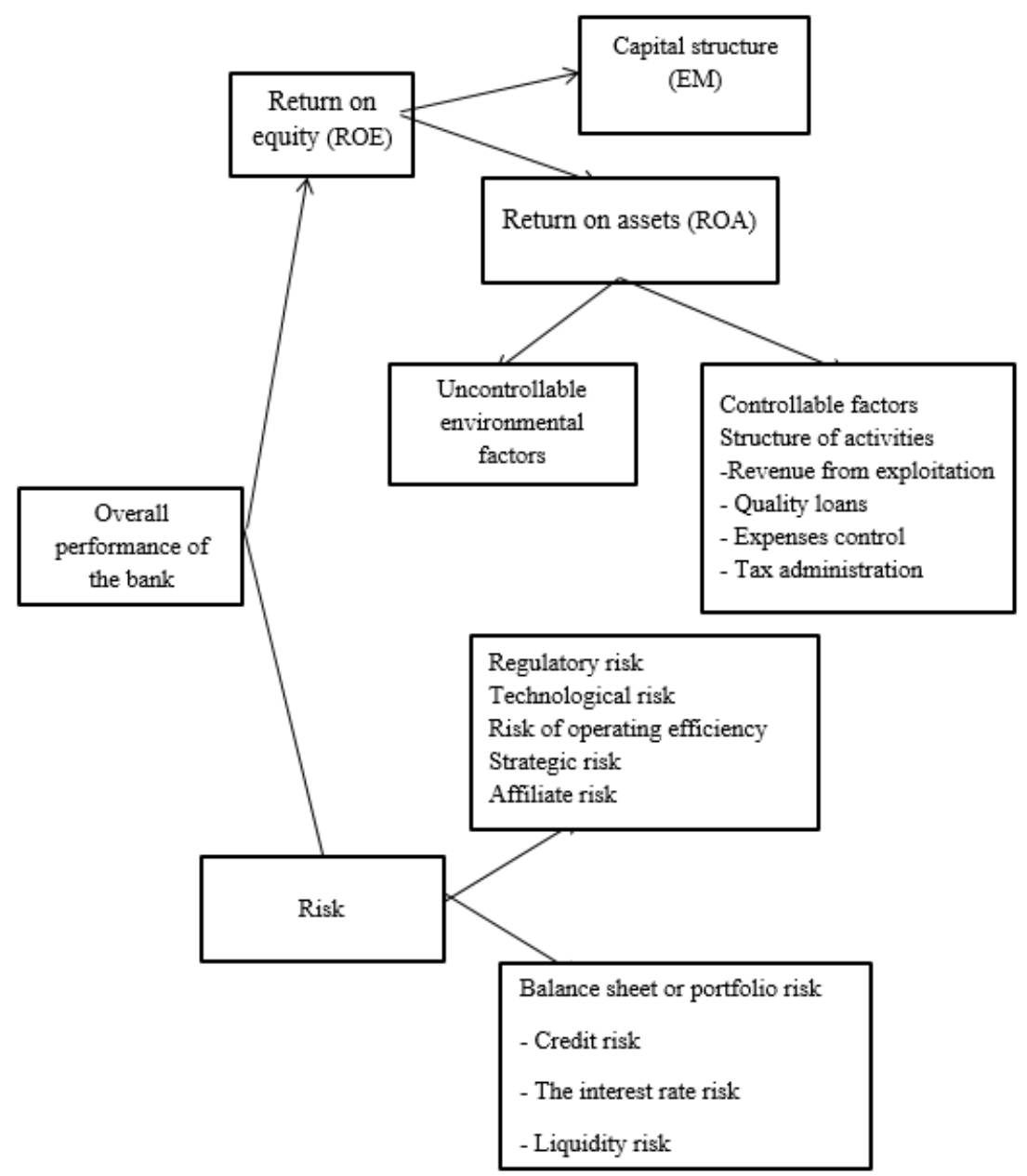

Figure 1. Scheme of risk-profit relationship for evaluating bank performance Source: Created by the author

The above chart shows that controllable and uncontrollable factors are determined for the return on assets. Factors over which banks have a degree of control include: credit quality, operating income, expenditure on checks, tax administration, types of business. In this scheme are highlighted the risks faced by a bank and that determines the variation of the capital return level: balance sheet or portfolio risk, regulatory risk, technological risk, efficiency operating risk, strategic risk, affiliation risk. The basic risks for the portfolio are credit risk, interest rate risk and liquidity risk.

One of the main bank's objectives is the profits optimization, the performance of the banking institution being an indication of the stability and confidence of the depositors, so that it must be encouraged to obtain the highest performances, for an efficient financial system.

Performance can be defined as the measure of stability of the bank's activity, with low levels of risk of any kind and a normal growth trend of profits from a time-assay.

\subsection{The main indicators for evaluating the performance of a banking institution}

In the specialized literature as well as in banking practice, various instruments for measuring and rendering banking performance are known, one of the most efficient being represented by the system of indicators. 
Indicators for assessing bank performance have great expressiveness, reflecting a variety of issues: the degree of profit-making, operational efficiency and management etc.

The main indicators for evaluating the performance of a banking institution are:

$>$ Economic rate return (ROA) - is determined as the ratio between the net profit and the total assets of the banks and expresses the profitability of the use of the assets, that is the net profit obtained by a monetary unit of assets.

ROA $=\frac{\text { Net profit }}{\text { Tatal assets }} \times 100$

$>$ Rate of financial return (ROE) - is determined as a ratio between net profit and equity, provides information on the profit recorded on the unit of book value of the shareholders' investment in the bank.

$\mathrm{ROE}=\frac{\text { Net profit }}{\text { Equity }} \times 100$

$>$ Leverage effect (EM - equity multiplier) or the capital Multiplier is a synthetic indicator that highlights the degree to which the use of additional resources attracted increases the return on equity. The capital Multiplier normally exceeds the value of 100 and means that the hiring of new resources is efficient for the bank, respectively when their cost is significantly lower than the asset rate. The indicator is calculated as follows:

$$
\mathrm{EM}=\frac{\text { Assets }}{\text { Captal }} \times 100
$$

$>$ Net profit rate (PM marginal profit) - is calculated as a percentage ratio between net profit and total income. In the banking field, the rate of profit is calculated, the size of which depends first of all on the ratio between the income and the expenses of the bank, and secondly on the structure of the revenues and costs of the banking activity.

$\mathrm{PM}=\frac{\text { Net profit }}{\text { Tatal incame }} \times 100$

$>$ Degree of use of assets (AU - asset utilisation) - represents an indicator that depends on the size of the interest rate on the market and the structure of the banking assets and is calculated as a percentage ratio between the total income from banking operations and the total assets, showing the total income obtained from the use of assets.

$$
\mathrm{AU}=\frac{\text { Tatal incame }}{\text { Tatal assets }} \times 100
$$

Based on the balance of the period analyzed and the profit and loss account, the necessary elements for the expression of profit indicators are determined.

The table below shows the indicators: the rate of economic return (ROA), the rate of financial return (ROE) and the leverage effect, in the period 2015-2019 in the Romanian banking system, according to BNR.

Table 1. Evolution of ROA, ROE and Leverage indicators during 2015-2019

\begin{tabular}{|c|l|l|l|}
\hline Years & \multicolumn{1}{|c|}{$\begin{array}{c}\text { ROA } \\
\mathbf{\%}\end{array}$} & \multicolumn{1}{c|}{$\begin{array}{c}\text { ROE } \\
\mathbf{\%}\end{array}$} & $\begin{array}{c}\text { Leverage effect } \\
\mathbf{\%}\end{array}$ \\
\hline $\mathbf{2 0 1 5}$ & 1,24 & 11,77 & 8,18 \\
\hline $\mathbf{2 0 1 6}$ & 1,08 & 10,42 & 8,92 \\
\hline $\mathbf{2 0 1 7}$ & 1,30 & 12,51 & 8,89 \\
\hline $\mathbf{2 0 1 8}$ & 1,55 & 14,58 & 9,34 \\
\hline $\mathbf{2 0 1 9}$ & 1,35 & 12,32 & 9,16 \\
\hline \multicolumn{2}{|l|}{ Source: Elaborated by the author, information available in the Financial Stability Reports, BNR } \\
\hline
\end{tabular}


The graph shows the evolution of ROA, ROE indicators and the leverage effect in Figure 1.
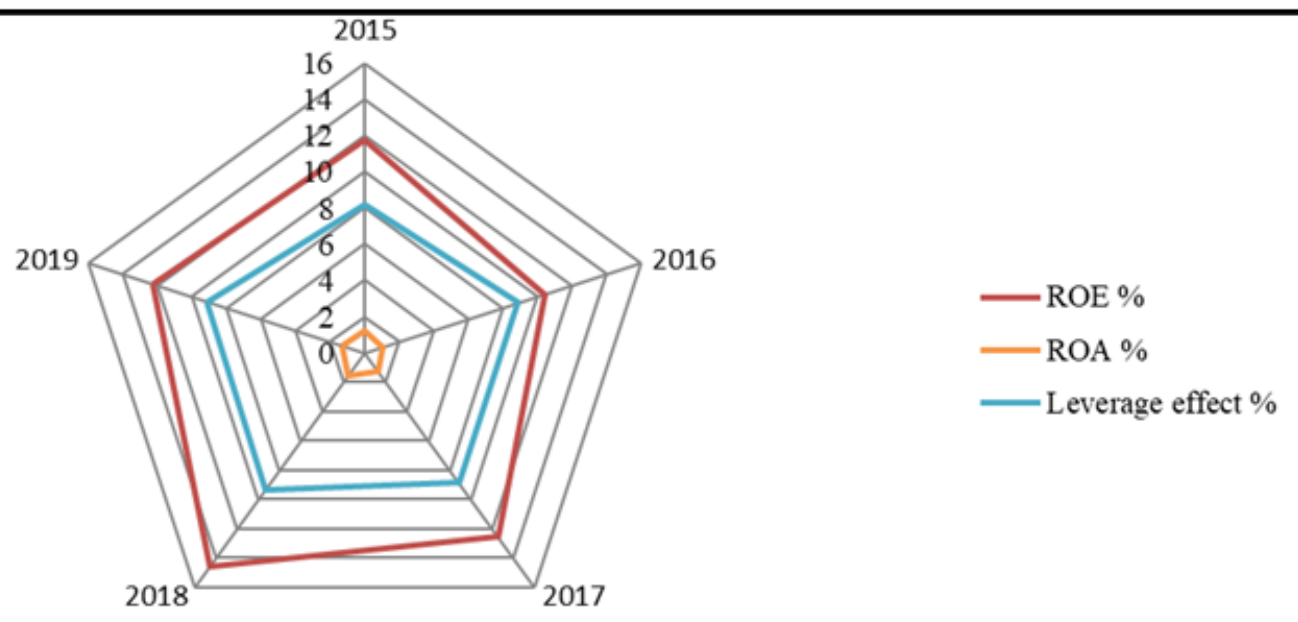

Figure 1. The evolution of ROA, ROE indicators and the leverage effect in Figure 1 during 2015-2019

Source: Elaborated by the author, information available in the Financial Stability Reports, BNR

The rate of economic return (ROA) during the period analyzed 2015-2019 registered a fluctuating evolution as follows: it decreased by $12.9 \%$ in 2016 compared to 2015 , increased by $20.37 \%$ in 2017 compared to 2016, increased by $19.23 \%$ in 2018 compared to 2017, and in 2019 it decreased by $12.9 \%$ compared to 2018.

The rate of financial return (ROE) has fluctuated as follows: it decreased by $11.46 \%$ in 2016 compared to 2015 , increased by $20.05 \%$ in 2017 compared to 2016 , increased by $16.54 \%$ in 2018 compared to 2017 , it decreased by $15.5 \%$ in 2019 compared to 2018.

Leverage effect in the period under review it showed an evolution like this: it increased by $9.04 \%$ in 2016 compared to 2015, it registered a slight decrease with $0.33 \%$ in 2017 compared to 2016, it increased by $5.06 \%$ in 2018 compared to 2017, and in 2019 it decreased by 1.92\% compared to 2018.

We conducted an analysis of the financial performance indicators in three banks we studied: Romanian Commercial Bank (BCR), BRD-Romanian Development Bank and Transilvania Bank.

Table 2. Calculation of key indicators of performance evaluation to BCR, BRD and Transilvania Bank in 2019

\begin{tabular}{|llll|}
\hline Indicators (\%) & BCR & BRD & Banca Transilvania \\
\hline ROA & 1,12 & 2,73 & 1,68 \\
\hline ROE & 10,03 & 19,35 & 16,54 \\
\hline Leverage effect & 8,91 & 7,07 & 9,82 \\
\hline Net profit rate & 52,18 & 48,21 & 47,3 \\
\hline The degree of assets use & 19,23 & 5,67 & 3,56 \\
\hline
\end{tabular}

Source: Made by the author, according to the financial data on the websites of the banking companies

The graph shows the evolution of the indicators at the 3 banking companies as in the Figure 2. 


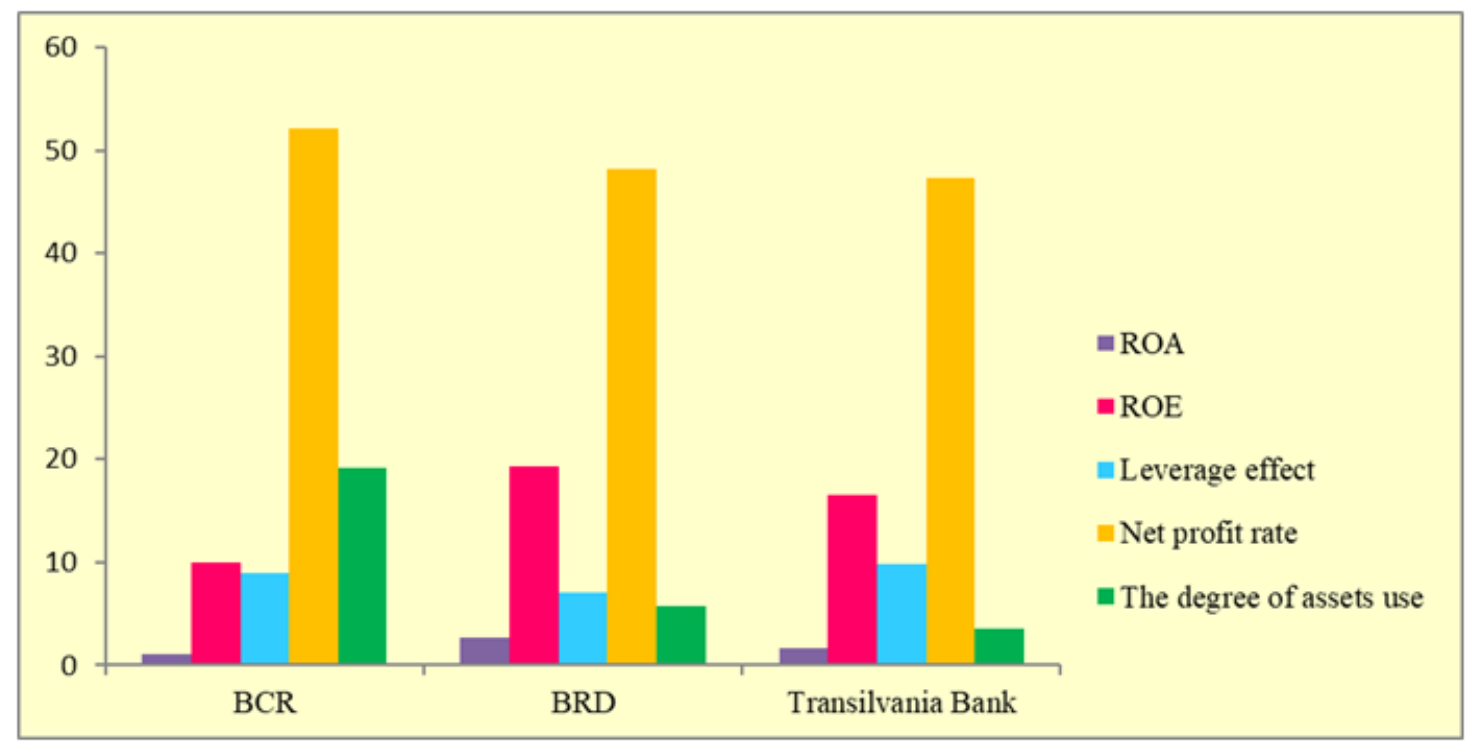

Figure 2. Evolution of the main performance evaluation indicators at BCR, BRD and Transilvania Bank in 2019

Source: Made by the author, according to the financial data on the websites of the banking companies

The rate of economic return (ROA) at the level of the three banking companies (BCR,BRD and Transilvania Bank) is the expression of the overall profitability of a bank. It is also called the profit on assets or the return on assets and measures the effect of the managerial ability to use the financial and real resources of the banking company in order to generate profit. In 2019, ROA recorded an evolution, so: 1,12\% at BCR, 2,73\% at BRD and 1,68\% at Transilvania Bank.

The rate of financial return (ROE) represents the most significant indicator of profit, which measures the results of banking management as a whole and gives an image on how to use the capital brought by the shareholders, the effect of engaging them in the bank's activity. In the case of the three banks analyzed, we note that they are within the normal range of this indicator of $10 \%$ and $30 \%$ respectively, recording the values: $10.03 \%$ BCR, 19.35\% BRD and 16.54\% Banca Transilvania.

The leverage effect measures the degree to which attracting and using new resources leads to an increase in capital returns.

The net profit rate in 2019 recorded the following values: $52,18 \%$ at BCR, $48,21 \%$ at BRD and $47,3 \%$ at Transilvania Bank.

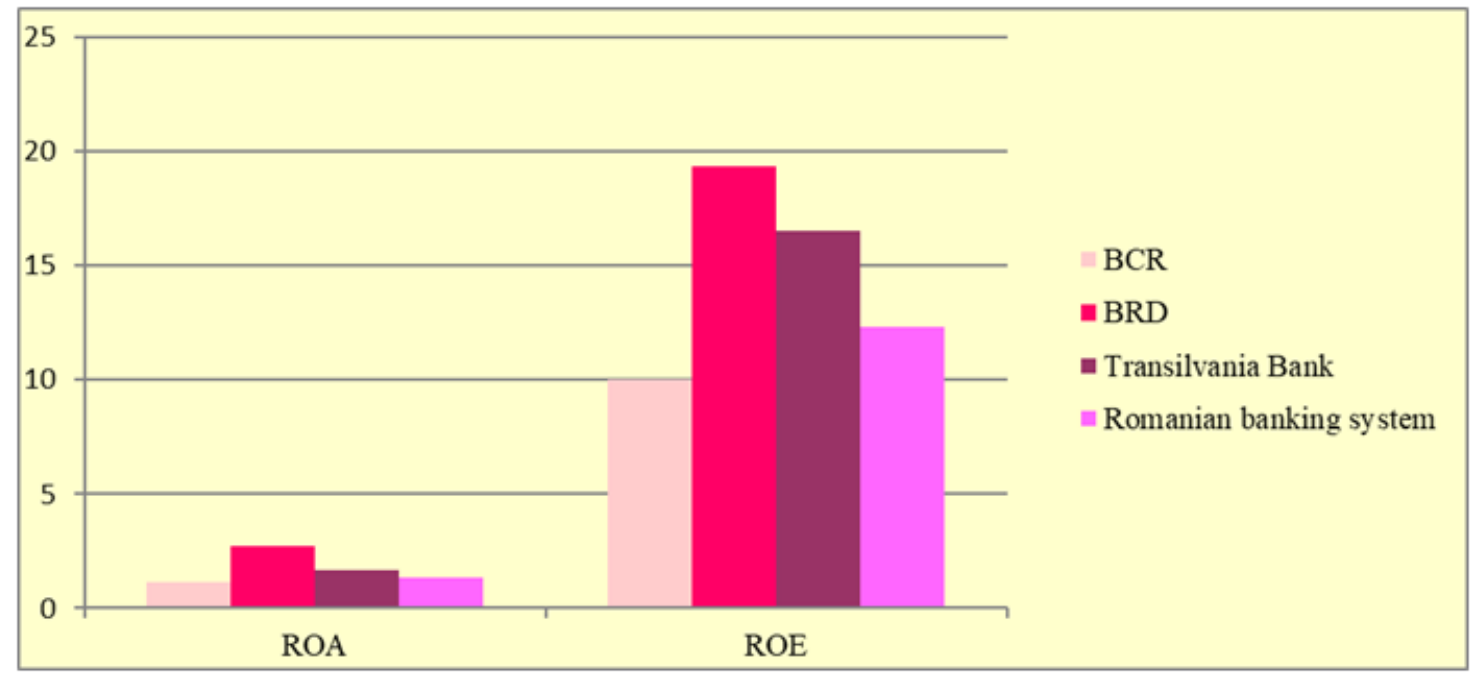

Figure 3. Evolution of ROA and ROE at BCR, BRD, Transilvania Bank and in the Romanian banking system in 2019

Source: Created by the author, according to the financial data from the websites of the banking companies and BNR website

The degree of use of the assets shows the total income that is obtained from the use of the assets. The size of this indicator depends on the size of the market interest rate and the structure of the bank assets. This indicator recorded the following values in 2019: 19,23\% at BCR, 5,67\% at BRD and 3,56\% at Transilvania Bank. Comparative analysis regarding the evolution of ROA and ROE in the Romanian banking system 
(according to BNR) and in the three banks analyzed (BCR, BRD and Transilvania Bank) in 2019. Thus, in the graph below we highlighted the evolution of ROE and ROA in the Romanian banking system and in BCR, BRD and Transilvania Bank.

The rate of economic return (ROA) in the banking system, as well as at the level of BCR, BRD and Transilvania Bank, is the expression of the overall profitability of a banking company.

The evolution of the rate of financial return (ROE) on the banking system compared to BRD and Transilvania Bank shows that the two banks are above the ROE of the banking system. This fact indicates an efficient risk management and a healthy lending policy by these two banks. At BCR, the rate of financial return was below the threshold recorded in the banking system, of $10.03 \%$ in 2019 .

The analysis regarding the rate of economic return (ROA) in the banking system and BCR, BRD and Transilvania Bank highlights the increased level of the bank's profit, especially at BRD, with the highest growth (19.35\% in 2019). As with the rate of financial return, BCR's economic rate of return decreased (1.12\% in 2019), reaching values below the level of the banking system.

\section{Risk analysis undertaken}

Risks taken by banking institutions are: loans risk, liquidity risk, interest rate risk, exchange risk and solvency risk.

\section{$>$ Credit risk}

The main indicator for analyzing this risk is:

\section{total loans}

$\overline{\text { total assets }}$

The greater the share of loans in total assets, the more risky the activity of the banking institution.

\section{$>$ Liquidity risk}

The main indicator for its measurement is:

$$
\frac{\text { loans }}{\text { deposits }}
$$

This report indicates the extent to which a bank can rely on its own resources in granting loans. When this report is subunit, the bank relies on its own resources in granting loans.

\section{The exchange risk}

The exchange risk is measured using the exchange position indicator, calculated as follows:

Exchange position $=$ total receivables - total commitments

\section{Solvency risk}

This risk is inversely proportional to the leverage effect and is calculated accordingly:

$$
\frac{\text { capital }}{\text { assets }}
$$

The bank with a higher indicator will better withstand a reduction in the value of the assets when the bank's depositors and creditors are in an unfavorable situation.

The analysis of the risks assumed at the three banking institutions BCR, BRD and Transilvania Bank is presented in the figure below:

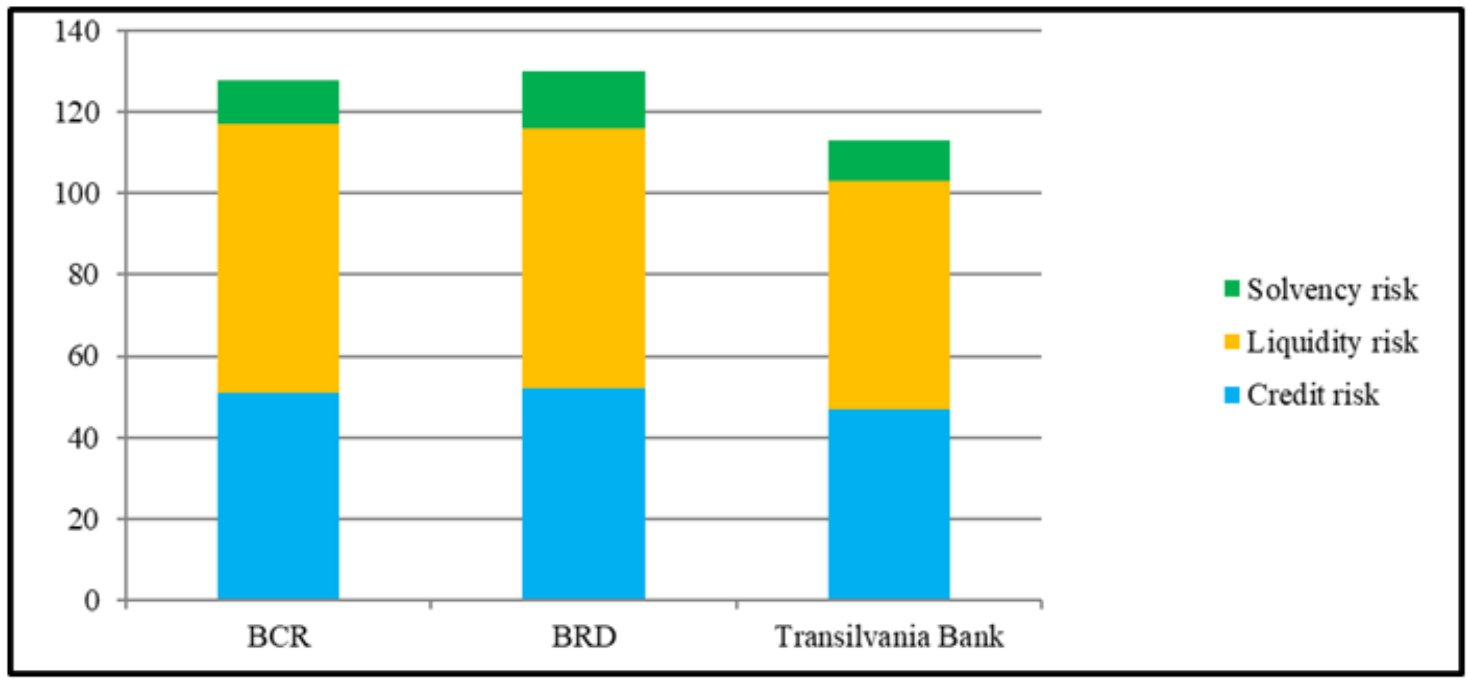

Figure 4. Analysis of the risks assumed at BCR, BRD and Transilvania Bank in 2019 Source: Created by author, according to financial data on the websites of the banks 
In Figure 4 we analyzed the credit, liquidity and solvency risks at the three banking institutions BCR, BRD and Transilvania Bank in 2019 according to the presented indicators. Therefore, the highest credit risk is registered at BRD following BCR and Transilvania Bank. In terms of liquidity risk, the highest value is recorded at BCR following BRD and Transilvania Bank. The solvency risk has the highest value registered in 2019 at BRD, following BCR and Transilvania Bank.

\section{Conclusions}

Banks operate according to the profitability criterion, as any commercial company, permanently pursuing net profit under specific risks (general economic evolution, restrictions imposed by the central bank, insolvency, financial structure of the bank), of which any bank must take into account the conduct of its activity.

Profitability is a revealing indicator of a bank's competitive position in the banking markets and the quality of its management, ensuring the health of the banking system.

Compared to other areas, banking is a particular one if we take into account both the bank's functions and the extremely volatile characteristics of most banking products and services, and for this reason, in the banking management a directly proportional link between profit and risk is mandatory.

Banks obviously want a higher profit from their activities and, in the same measure, minimize the risks, which is why banking performance first of all aims to determine the soundness of the bank, its degree of exposure to various categories of risk and then of its efficiency level.

\section{References}

1. 1.Basno, C., Dardac, N., Floricel, C. - Monedă, Credit, Bănci. Aplicaţii şi Studii de Caz. Editura Didactică şi Pedagogică, Bucureşti, 2003.

2. Basno, C., Dardac, N. - Management bancar. Editura Economică, Bucureşti, 2002.

3. Bătrâncea, I. - Raportări financiare, Editura Risoprint, Cluj-Napoca,2006.

4. 4.Bătrâncea, I., Trenca, I., Bejenaru, A., Borlea, S. - Analiza performanţelor şi riscurilor bancare, Editura Risoprint, Cluj-Napoca, 2008.

5. Beju, D. - Mecanisme monetare și instituţii bancare, Editura Casa Cărții de Stiinţă, Cluj-Napoca, 2005.

6.Cocriș V., Andrieș A.- Managementul riscurilor și al performanțelor bancare, București, 2009.

Cohen, I.K. - Focus and Financial Management, Imperial College Press, London, 2005.

8.Crouhy, M., Galai, D. \& Mark, M.- The Essential of Risk Management, Edited by, McGraw-Hill Companies, Chicago, U.S.A, 2006.

9.Dardac N.- Monedă și credit, disponibil la http://www.biblioteca-digitala.ase.ro/biblioteca/carte2.asp?id=99\&idb=8

10. Dardac, N., Barbu, T. - Monedă, Bănci şi Politici Monetare, Editura Didactică şi Pedagogică, R.A., București, 2006.

11. Dănilă, N., Berea A.O. - Management bancar, Editura Economică, București, 2000.

12. Dedu, V.- Gestiune și audit bancar, Editura Economică, București, 2003.

13. 13.Gorrod, M. - Risk Management Systems. Process, Technology and Trends, Palgrave Macmillan, New York, 2004.

14. Rădoi A.M.- Gestiune bancară, Editura Economică, București, 2009.

15. Rotaru, C. - Managementul performanței bancare, Editura Expert, București, 2001.

16. 16.Trenca, I. - Metode și tehnici bancare-principii, reglementări, experiențe, Editura Casa Cărţii de Ştiinţă, Cluj-Napoca, 2002.

17. 17.Trenca, I.- Fundamente ale managementului financiar, Editura Casa Cărţii de Ştiinţă, ClujNapoca, 2005.

18. 18.Trenca, I., Bătrâncea, I., Mitrache, R., Bătrâncea, L.-M., Borlea, S. N. - Transferuri bancare, Editura Risoprint, Cluj-Napoca, 2007.

19. 19.Turliuc, V., Cocris, V., Boariu, A., Stoica, O., Dornescu, V., Chirleșan, D. - Monedă și credit, Editura Economică, București, 2005.

20. www.bnr.ro Banca Națională a României 